\title{
Comparison and Modeling of Aqueous Dissolution Rates of Various Uranium Oxides
}

\author{
S.A. Steward \\ E.T. Mones
}

This paper was prepared for submittal to the Materials Research Society Fall Meeting

Boston, $M A$

December 2-6, 1996

November 1996

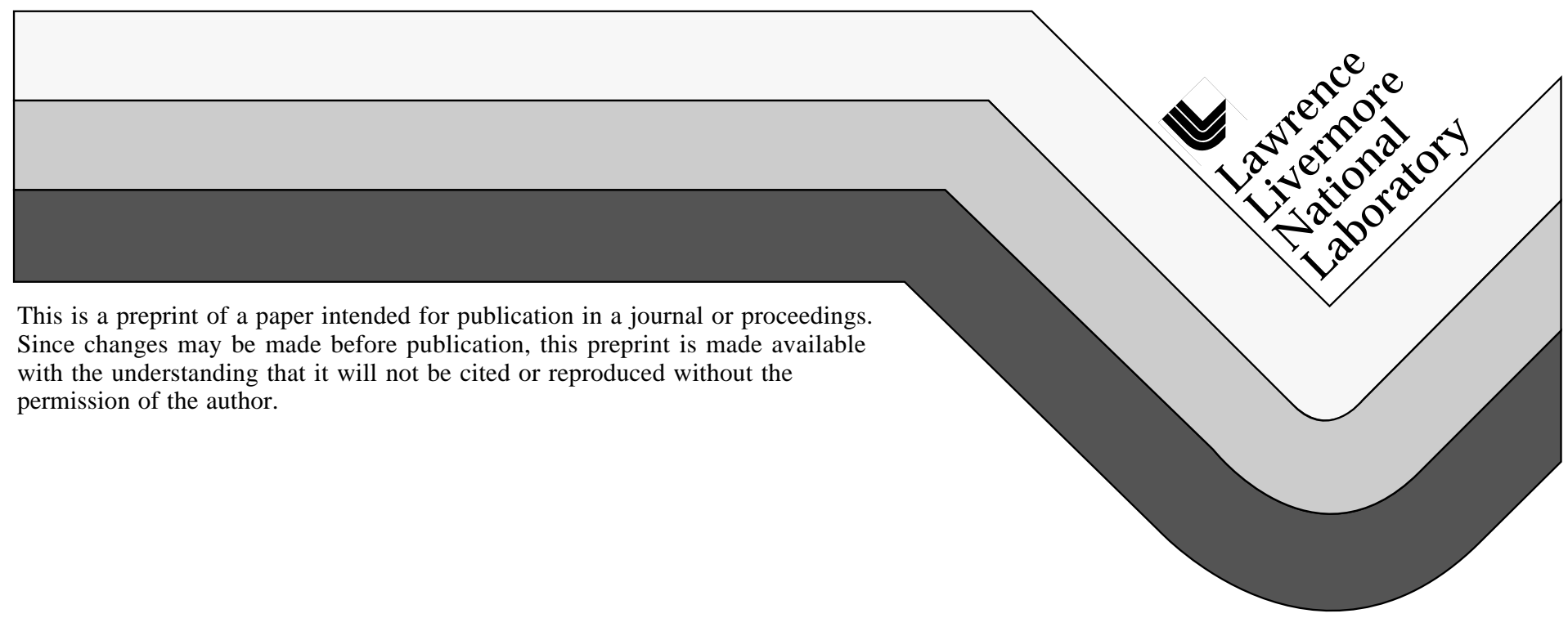




\section{DISCLAIMER}

This document was prepared as an account of work sponsored by an agency of the United States Government. Neither the United States Government nor the University of California nor any of their employees, makes any warranty, express or implied, or assumes any legal liability or responsibility for the accuracy, completeness, or usefulness of any information, apparatus, product, or process

disclosed, or represents that its use would not infringe privately owned rights. Reference herein to any specific commercial product, process, or service by trade name, trademark, manufacturer, or otherwise, does not necessarily constitute or imply its endorsement, recommendation, or favoring by the United States Government or the University of California. The views and opinions of authors expressed herein do not necessarily state or reflect those of the United States Government or the University of California, and shall not be used for advertising or product endorsement purposes. 


\title{
COMPARISON AND MODELING OF AQUEOUS DISSOLUTION RATES OF VARIOUS URANIUM OXIDES
}

\author{
S. A. STEWARD and E. T. MONES \\ Lawrence Livermore National Laboratory, P.O. Box 808, Livermore, CA 94550
}

\begin{abstract}
The purpose of this work has been to measure and model the intrinsic dissolution rates of uranium oxides under a variety of well-controlled conditions that are relevant to a geologic repository. When exposed to air at elevated temperature, spent fuel may form the stable phase $\mathrm{U}_{3} \mathrm{O}_{8}$. Dehydrated schoepite, $\mathrm{UO}_{3} \cdot \mathrm{H}_{2} \mathrm{O}$, has been shown to exist in drip tests on spent fuel.

Equivalent sets of $\mathrm{U}_{3} \mathrm{O}_{8}$ and $\mathrm{UO}_{3} \cdot \mathrm{H}_{2} \mathrm{O}$ dissolution experiments allowed a systematic examination of the effects of temperature $\left(25-75^{\circ} \mathrm{C}\right), \mathrm{pH}(8-10)$ and carbonate $\left(2-200 \times 10^{-4}\right.$ molar $)$ concentrations at atmospheric oxygen conditions.

Results indicate that $\mathrm{UO}_{3} \cdot \mathrm{H}_{2} \mathrm{O}$ has a much higher dissolution rate (at least ten-fold) than $\mathrm{U}_{3} \mathrm{O}_{8}$ under the same conditions. The intrinsic dissolution rate of unirradiated $\mathrm{U}_{3} \mathrm{O}_{8}$ is about twice that of $\mathrm{UO}_{2}$. Dissolution of both $\mathrm{U}_{3} \mathrm{O}_{8}$ and $\mathrm{UO}_{3} \cdot \mathrm{H}_{2} \mathrm{O}$ shows a very high sensitivity to carbonate concentration. Present results show a 25 to 50 -fold increase in room-temperature $\mathrm{UO}_{3} \cdot \mathrm{H}_{2} \mathrm{O}$ dissolution rates between the highest and lowest carbonate concentrations.

As with the $\mathrm{UO}_{2}$ dissolution data the classical observed chemical kinetic rate law was used to model the $\mathrm{U}_{3} \mathrm{O}_{8}$ dissolution rate data. The $\mathrm{pH}$ did not have much effect on the models, in agreement with the earlier analysis of the $\mathrm{UO}_{2}$ and spent fuel dissolution data,. However, carbonate concentration, not temperature, had the strongest effect on the $\mathrm{U}_{3} \mathrm{O}_{8}$ dissolution rate. The $\mathrm{U}_{3} \mathrm{O}_{8}$ dissolution activation energy was about $6000 \mathrm{cal} / \mathrm{mol}$, compared with 7300 and 8000 $\mathrm{cal} / \mathrm{mol}$ for spent fuel and $\mathrm{UO}_{2}$ respectively.
\end{abstract}

\section{INTRODUCTION}

Understanding the long-term dissolution of spent fuel in groundwater is necessary for its safe disposal in a geological repository. Radionuclides could be released from such a repository by dissolution and transport processes in flowing groundwater. The dissolution of the $\mathrm{UO}_{2}$ spent fuel matrix is regarded as the rate-limiting step for release of radioactive fission products. Therefore, the intrinsic $\mathrm{UO}_{2}$ dissolution rate sets an upper limit on the aqueous radionuclide release rate. If the $\mathrm{UO}_{2}$ in the spent fuel matrix contacts air and is oxidized further, then these dissolution responses also must be measured.

It is commonly assumed that oxidized fuel would dissolve faster than its unoxidized predecessor. The purpose of this and previous work has been to measure the intrinsic dissolution rates of uranium oxides, as well as unoxidized and oxidized spent fuel, under a variety of wellcontrolled conditions that are relevant to a geological repository and allow for subsequent modeling. When exposed to air at elevated temperature, spent fuel may form the stable phase $\mathrm{U}_{3} \mathrm{O}_{8}$. A form of the trioxide, dehydrated schoepite, $\mathrm{UO}_{3} \cdot \mathrm{H}_{2} \mathrm{O}$, has been shown to exist in drip tests on spent fuel [1]. The results of essentially identical dissolution experiments performed on 
depleted $\mathrm{U}_{3} \mathrm{O}_{8}$ and $\mathrm{UO}_{3} \cdot \mathrm{H}_{2} \mathrm{O}$ will be compared. These are in turn compared with earlier work on spent fuel and $\mathrm{UO}_{2}$ under similar conditions [2].

Water from wells near Yucca Mountain contain typical aqueous constituents, such as carbonates, sulfates, chlorides, silicates, and calcium. Of the anions commonly found in groundwater, bicarbonate is considered to be the most aggressive towards uranium oxides, forming complexes with the uranyl $\left(\mathrm{UO}_{2}{ }^{+2}\right)$ cation. This makes the carbonates good surrogates for all anions in aggressive groundwater. Statistical experimental design was used to plan the set of $\mathrm{U}_{3} \mathrm{O}_{8}$ and $\mathrm{UO}_{3} \cdot \mathrm{H}_{2} \mathrm{O}$ dissolution experiments. This approach allows a systematic examination of the effects of temperature, $\mathrm{pH}$ and carbonate concentrations on the dissolution rates of these two oxides. It also minimizes the number of experiments required, and provides a robust data set suitable for modeling and comparison with the previously reported $\mathrm{UO}_{2}$ dissolution data. Because of the already elevated oxidation state, these experiments were run only at $8 \mathrm{ppm}$ dissolved oxygen in the leaching solutions, equivalent to 0.2 atmosphere oxygen in air. The dissolution rates from the design allow a fit to a second-order model in all variables, including interactions between the variables. Additional experiments on $\mathrm{UO}_{2}$ complete a matrix of dissolution rates measured on all three oxides at the same conditions.

\section{EXPERIMENTAL}

As with previous studies $[2,3,4]$, the intrinsic dissolution rates of the uranium oxides were determined by using a single pass flow-through method. Flow rates and specimen size can be controlled with this approach so that the oxides dissolve under conditions that are far from solution saturation (no precipitation of dissolved products). Thus, the dependence of $\mathrm{UO}_{\mathrm{X}}$ dissolution kinetics on $\mathrm{pH}$, temperature, oxygen and carbonate/bicarbonate concentrations can be evaluated.

Experiments at three different values of each variable were required, in order to test for nonlinear effects of the three variables on the uranium dissolution rates. The chosen variable ranges were $\mathrm{pH}$ 's of 8 to 10 , temperatures of $25^{\circ}$ to $75^{\circ} \mathrm{C}$, total carbonate concentrations of 0.2 to $20 \mathrm{millimol} / \mathrm{L}$ and $8 \mathrm{ppm}$ dissolved oxygen. The carbonate concentrations bracketed the typical groundwater concentration of $1 \mathrm{millimol} / \mathrm{L}$. The $\mathrm{pH}$ range covered a value typical of groundwaters $(\mathrm{pH}=8)$ to very alkaline conditions. The dissolved oxygen concentration is the value at atmospheric pressure.

A model that can discriminate nonlinear effects and interactions of the three variables for both oxides has at least 14 terms. A sixteen experiment design is, therefore, the minimum number of experiments required for a numerical regression fit, with extra degrees of freedom to account for experimental variability. For each oxide, a classical three-level, full-factorial experimental design consists of the $27\left(3^{3}\right)$ possible combinations of variable settings from the three variables at low, medium and high values. Performing such a large number of 54 experiments was unrealistic. The first 16 experiments listed in Table 1 are a D-optimal design chosen using the RS/Discover computer program from BBN Software [5]. This group represents one of many equivalent designs that could be picked from the candidate set of 54 experiments. For example, if the experiments for the two oxidation states were reversed, an equally good design would result.

The first eight experiments in Table 1, four for each oxide, are a screening design that tests whether each variable has any significant effect on dissolution rate. The D-optimal approach significantly reduced the number of experiments required by classic full- or fractional-factorial designs. These experiments are uniformly distributed over the three-dimensional variable space. The additional eight tests (17-24) in Table 1 were added to the design and represent opposing temperature conditions for those experiments not having a temperature pair in the first 16 runs. These 24 runs include all of the eight possible combinations of the three variables at extreme 
settings for both oxides, as well as the eight runs with at least one mid-level variable setting needed for non-linear modeling. Run 25 was added so that a dissolution rate for $\mathrm{UO}_{3} \cdot \mathrm{H}_{2} \mathrm{O}$ would be available at the same condition as already obtained for the other two oxides.

Both $\mathrm{U}_{3} \mathrm{O}_{8}$ and $\mathrm{UO}_{3} \cdot \mathrm{H}_{2} \mathrm{O}$ samples were powders because of the synthetic routes available for each. The $\mathrm{U}_{3} \mathrm{O}_{8}$ powders were National Bureau of Standards (NBS or NIST) Standard Reference Material (SRM) 750(b). $\mathrm{U}_{3} \mathrm{O}_{8}$ is the most stable of the uranium oxides and is easily produced by the well known method of heating a uranium compound, $\mathrm{UO}_{2}$ in this case, to several hundred degrees Celsius in air. The dehydrated schoepite was synthesized via hydrolysis of analytical grade uranyl acetate in a glass distillation apparatus, with continuous additions of water to replace the acetic acid boiled off during the synthesis [6]. Surface areas of both were measured via the traditional BET method using xenon gas. The resulting surface area for the $\mathrm{U}_{3} \mathrm{O}_{8}$ is $0.18 \pm 0.02$

$\mathrm{m}^{2} / \mathrm{g}$ and $0.31 \pm 0.04 \mathrm{~m}^{2} / \mathrm{g}$ for the $\mathrm{UO}_{3} \cdot \mathrm{H}_{2} \mathrm{O}$. X-ray Diffraction (XRD) of both materials indicated they were the correct phases. Particle size distributions were also determined by means of sedimentation techniques. The median particle size for the $\mathrm{U}_{3} \mathrm{O}_{8}$ powder was $2.1 \mu \mathrm{m}$ with a 25-75 percentile range of 1.0 to $2.8 \mu \mathrm{m}$. The median particle size for the $\mathrm{UO}_{3} \cdot \mathrm{H}_{2} \mathrm{O}$ powder was $4.1 \mu \mathrm{m}$ with a $25-75$ percentile range of 2.5 to $5.5 \mu \mathrm{m}$.

Test solutions were prepared using analytical-reagent grade chemicals and deionized water. Each solution was continuously sparged with argon gas containing fixed concentrations of oxygen and carbon dioxide to maintain the desired dissolved oxygen concentration and $\mathrm{pH}$ of the solution. The test solutions flowed through stainless steel sample cells at rates between 5 and $25 \mathrm{~mL} / \mathrm{hr}$. Several times per week, effluent from the cells was collected, acidified to prevent uranium adsorption on the sample vial walls, and analyzed for uranium content using a phosphorescence analyzer. Dissolution rates were calculated from uranium concentrations multiplied by flow rates and divided by surface areas of the test specimens. After steady-state dissolution rates were achieved, the flow rates were occasionally changed to ensure that the observed dissolution rates remained unchanged. Dissolution rates will not be affected by changing flow rates, if the reaction is not solubility- or diffusion-limited.

\section{RESULTS}

The 25 measured dissolution rates of $\mathrm{U}_{3} \mathrm{O}_{8}$ and $\mathrm{UO}_{3} \cdot \mathrm{H}_{2} \mathrm{O}$ at atmospheric oxygen are shown in Table 1, as well as the actual values for the three independent variables, temperature, carbonate concentration and $\mathrm{pH}$. Most experiments lasted about a month. The dissolution rates are the average values after reaching steady-state. The values preceded by an approximation or greaterthan sign are estimates, because steady-state could not be reached or the sample was dissolving too rapidly. Rapid sample dissolution was particularly true for the dehydrated schoepite. Table 2 lists the uranium dissolution rates for the three oxides, $\mathrm{UO}_{2}, \mathrm{U}_{3} \mathrm{O}_{8}$ and $\mathrm{UO}_{3} \cdot \mathrm{H}_{2} \mathrm{O}$, that were measured under atmospheric oxygen conditions. Because the measured values of the independent variables differ between runs, only their nominal values are listed in Table 2. Two new $\mathrm{UO}_{2}$ results were measured at a pH of 10 and $2 \times 10^{-4}$ molar total carbonate and a $\mathrm{pH}$ of 10 at $2 \times 10^{-2}$ molar total carbonate. These were acquired so that there would be a full set of eight measurements at the extreme conditions (a full-factorial linear experimental design) for each oxide. Available results for spent fuel [2] are listed at equivalent conditions. To facilitate easier comparisons of the dissolution rates and variable effects, the results for the eight experimental conditions at the high and low values of each variable are grouped together as Part 1 of Table 2. They are grouped first by $\mathrm{pH}$, then by carbonate concentration and finally by temperature. The results at intermediate conditions are listed in Part 2 of Table 2 using the same grouping scheme. 
The oxide phase has by far the strongest effect on the uranium dissolution rate. The rate increases significantly in going from $\mathrm{UO}_{2}$ to $\mathrm{U}_{3} \mathrm{O}_{8}$ and dramatically from $\mathrm{U}_{3} \mathrm{O}_{8}$ to $\mathrm{UO}_{3} \cdot \mathrm{H}_{2} \mathrm{O}$. The $\mathrm{UO}_{3} \cdot \mathrm{H}_{2} \mathrm{O}$ dissolution is so rapid that the samples disappear within a few days at the high carbonate levels. With the $\mathrm{U}_{3} \mathrm{O}_{8}$, unlike $\mathrm{UO}_{2}$, carbonate affects the dissolution rate to a greater extent than does temperature. Increasing temperature shows its expected effect of enhancing the dissolution rate. The enhancement is particularly strong at the highest carbonate concentration. The data indicate that alkaline $\mathrm{pH}$ is the least significant factor in dissolution of spent fuel or any of the uranium oxides under the alkaline conditions of these experiments, although it seems more important in $\mathrm{UO}_{3} \cdot \mathrm{H}_{2} \mathrm{O}$ dissolution. The $\mathrm{UO}_{3} \cdot \mathrm{H}_{2} \mathrm{O}$ dissolution data show strong nonlinearities in dissolution response to all of the variables, $\mathrm{pH}$, temperature and carbonate concentrations. These nonlinearities may only be due to the difficulties in determining appropriate $\mathrm{UO}_{3} \cdot \mathrm{H}_{2} \mathrm{O}$ dissolution rates. A comparison of the leachate and prepared solution $\mathrm{pH}$ 's of the $\mathrm{UO}_{3} \cdot \mathrm{H}_{2} \mathrm{O}$ experiments in Table 2 shows that the solution $\mathrm{pH}$ sometimes drops upon contact with $\mathrm{UO}_{3} \cdot \mathrm{H}_{2} \mathrm{O}$, particularly at low carbonate concentrations. The $\mathrm{UO}_{3} \cdot \mathrm{H}_{2} \mathrm{O}$ seems to act as a Brønsted acid by donating a proton. Where the carbonate concentration is low there is less buffering capacity of the solution.

Because $\mathrm{U}_{3} \mathrm{O}_{8}$ has both $\mathrm{U}(\mathrm{IV})$ and $\mathrm{U}(\mathrm{VI})$ valence states, its dissolution rates might be expected to be between that of $\mathrm{UO}_{2}$ and $\mathrm{UO}_{3} \cdot \mathrm{H}_{2} \mathrm{O}$, particularly as carbonate concentrations increase. That does not seem consistently to be the case with the present data. Perhaps the U(IV) cations in the structure impede the overall dissolution rate because of the change in oxidation state required.

\section{MODELING}

Only the fourteen $\mathrm{U}_{3} \mathrm{O}_{8}$ dissolution rate data given in Table 2 were modeled. Because the $\mathrm{UO}_{3} \cdot \mathrm{H}_{2} \mathrm{O}$ dissolved so rapidly, their dissolution rates are estimates or minima and not appropriate for modeling. As with the $\mathrm{UO}_{2}$ dissolution data several approaches to $\mathrm{U}_{3} \mathrm{O}_{8}$ dissolution modeling are being explored. Again the classical observed chemical kinetic rate law was used and takes the following well-known general form [7]:

Rate $=k[A]^{a}[B]^{b}[C]^{c} \ldots \exp \left(-E_{a} / R T\right)$,

This generalized form of the rate law is for homogeneous gas or liquid reaction systems. It does not take into consideration the possibly complex liquid-solid reaction at the $\mathrm{UO}_{\mathrm{x}}$ or spent fuel surface. Additional term(s) are needed to account for this element of the reaction, and any radiation effects in the spent fuel, but they are unknown at this time. Other function forms are being considered. An Onsager-type thermodynamic function provides a classical relationship for dissolution rate and is linearly related to the energy change of the solid dissolving into a liquid. This is expected to be descriptive of dissolution response close to thermodynamic equilibrium. A form of the Butler-Volmer equation, used in correlation of corrosion and electrochemical rate data, is also being examined. The normal derivation of the Butler-Volmer equations also assumes that the electrochemical processes are near thermodynamic equilibrium.

Only regression fits of the $\mathrm{U}_{3} \mathrm{O}_{8}$ dissolution rate data to the classical chemical kinetic rate law are discussed here, for comparison with the previously reported $\mathrm{UO}_{2}$ and spent fuel models. Model parameters are presented, based on both the leachate $\mathrm{pH}$ 's used in the $\mathrm{UO}_{2}$ dissolution 
models, and the pH's of the original carbonate solutions, before contact with the $\mathrm{UO}_{2}$ or spent fuel samples, as used previously for the spent fuel data. The pH's of the fresh carbonate leaching solutions are probably more representative of the $\mathrm{pH}$ at the sample than the $\mathrm{pH}$ of the leachate analysis sample that has been exposed to dissolved $\mathrm{CO}_{2}$ from the air.

The following equation was fitted using the measured leachate $\mathrm{pH}$ 's given in Table 1:

$\mathrm{U}_{3} \mathrm{O}_{8}$ (leachate $\mathrm{pH}$ 's):

$\log (\mathrm{DR})\left\{\mathrm{mgU} / \mathrm{m}^{2} \cdot \mathrm{day}\right\}=$

$7.832+0.6910 \cdot \log _{10}\left[\mathrm{CO}_{3}\right]+0.0860 \cdot \log _{10}[\mathrm{H}]-1317 / \mathrm{T}$

$\mathrm{r}^{2}=0.87$.

Using the pH's of the prepared carbonate solutions, also given in the same column of the table, we arrive at similar, but perhaps more accurate, coefficients:

$\mathrm{U}_{3} \mathrm{O}_{8}$ (carbonate soln. $\mathrm{pH}$ 's):

$\log (\mathrm{DR})\left\{\mathrm{mgU} / \mathrm{m}^{2} \cdot \mathrm{day}\right\}=$

$7.951+0.6492 \cdot \log _{10}\left[\mathrm{CO}_{3}\right]+0.1065 \cdot \log _{10}[\mathrm{H}]-1333 / \mathrm{T}$

$\mathrm{r}^{2}=0.88$.

As with the earlier $\mathrm{UO}_{2}$ and spent fuel dissolution data, the $\mathrm{pH}$ did not have much effect on the model. However, carbonate concentration, not temperature, had the strongest effect on the $\mathrm{U}_{3} \mathrm{O}_{8}$ dissolution rate. The temperature had half the effect of carbonate concentration on the uranium dissolution rate. The $\mathrm{pH}$ was only about one-sixth as effective as carbonate concentration in explaining the changes in $\mathrm{U}_{3} \mathrm{O}_{8}$ dissolution rates. Leaving out the $\mathrm{pH}$ term had a negligible effect on the other coefficients and was absorbed in the constant:

$\mathrm{U}_{3} \mathrm{O}_{8}$ (carbonate soln. pH's):

$\log (\mathrm{DR})\left\{\mathrm{mgU} / \mathrm{m}^{2} \cdot \mathrm{day}\right\}=$ $6.925+0.6486 \cdot \log _{10}\left[\mathrm{CO}_{3}\right]-1307 / \mathrm{T}$

$\mathrm{r}^{2}=0.86$.

Temperature and carbonate concentration show significant interaction. The $\mathrm{pH}$ shows its importance through interaction with carbonate as well. Additions of cross terms for those interactions to equation 4 improves the fit significantly, with a correlation coefficient of 0.95 .

To allow comparisons with this $\mathrm{U}_{3} \mathrm{O}_{8}$ dissolution data, the previously reported spent fuel and $\mathrm{UO}_{2}$ atmospheric oxygen models [2] are reproduced in equations 5 and 6. For consistency the $\mathrm{UO}_{2} 20 \%$ oxygen data were refitted using the fresh carbonate solution pH's and is shown in eq.7. This regression fit had a increased correlation coefficient, compared with the original fit using the leachate $\mathrm{pH}$ 's (eq. 6). There was a larger change in the coefficients, than with the $\mathrm{U}_{3} \mathrm{O}_{8}$ results fitted with the two $\mathrm{pH}$ sets.

Spent Fuel, ATM-103 (20\% oxygen only, carbonate soln. pH's):

$\log (\mathrm{DR})\left\{\mathrm{mgU} / \mathrm{m}^{2} \cdot\right.$ day $\}=$

$7.202+0.2260 \cdot \log _{10}\left[\mathrm{CO}_{3}\right]+0.0905 \cdot \log _{10}[\mathrm{H}]-1628 / \mathrm{T}$ 
$\mathrm{r}^{2}=0.95$.

$\mathrm{UO}_{2}$ (20\% oxygen only, leachate $\mathrm{pH}$ 's):

$\log (\mathrm{DR})\left\{\mathrm{mgU} / \mathrm{m}^{2} \cdot\right.$ day $\}=$

$4.650+0.2742 \cdot \log _{10}\left[\mathrm{CO}_{3}\right]-0.1868 \cdot \log _{10}[\mathrm{H}]-1501 / \mathrm{T}$

$\mathrm{r}^{2}=0.79$.

$\mathrm{UO}_{2}$ (20\% oxygen only, carbonate soln. pH's):

$\log (\mathrm{DR})\left\{\mathrm{mgU} / \mathrm{m}^{2} \cdot\right.$ day $\}=$

$5.828+0.3335 \cdot \log _{10}\left[\mathrm{CO}_{3}\right]-0.1571 \cdot \log _{10}[\mathrm{H}]-1734 / \mathrm{T}$

$\mathrm{r}^{2}=0.83$.

\section{CONCLUSIONS}

The aim of this work has been the measurement of the intrinsic dissolution rates of uranium oxides under a variety of well-controlled conditions. These experiments are relevant to a geological repository and allow for modeling. After exposure to air at elevated temperature, the stable phase $\mathrm{U}_{3} \mathrm{O}_{8}$ may form from spent fuel. Formation of dehydrated schoepite, $\mathrm{UO}_{3} \cdot \mathrm{H}_{2} \mathrm{O}$, has been found in drip tests with spent fuel.

Equivalent sets of $\mathrm{U}_{3} \mathrm{O}_{8}$ and $\mathrm{UO}_{3} \cdot \mathrm{H}_{2} \mathrm{O}$ dissolution experiments allowed a systematic

examination of the effects of temperature $\left(25-75^{\circ} \mathrm{C}\right), \mathrm{pH}(8-10)$ and carbonate $\left(2-200 \times 10^{-4}\right.$ molar $)$ concentrations at atmospheric oxygen conditions.

Results indicate that $\mathrm{UO}_{3} \cdot \mathrm{H}_{2} \mathrm{O}$ has a much higher dissolution rate (at least ten-fold) than $\mathrm{U}_{3} \mathrm{O}_{8}$. Dissolution of both $\mathrm{U}_{3} \mathrm{O}_{8}$ and $\mathrm{UO}_{3} \cdot \mathrm{H}_{2} \mathrm{O}$ shows a very high sensitivity to carbonate concentration. Present results show a 25 to 50 -fold increase in room-temperature $\mathrm{UO}_{3} \cdot \mathrm{H}_{2} \mathrm{O}$ dissolution rates between the highest and lowest carbonate concentrations. The intrinsic dissolution rate of unirradiated $\mathrm{U}_{3} \mathrm{O}_{8}$ is about twice that of $\mathrm{UO}_{2}$ under similar conditions.

As with the $\mathrm{UO}_{2}$ dissolution data the classical observed chemical kinetic rate law was used to model the $\mathrm{U}_{3} \mathrm{O}_{8}$ dissolution rate data. The $\mathrm{pH}$ did not have much effect on the models, in concert with the earlier $\mathrm{UO}_{2}$ and spent fuel dissolution data,. However, carbonate concentration, not temperature, had the strongest effect on the $\mathrm{U}_{3} \mathrm{O}_{8}$ dissolution rate. The $\mathrm{U}_{3} \mathrm{O}_{8}$ dissolution activation energy was about $6000 \mathrm{cal} / \mathrm{mol}$, compared with 7300 and $8000 \mathrm{cal} / \mathrm{mol}$ for spent fuel and $\mathrm{UO}_{2}$ respectively.

\section{ACKNOWLEDGMENTS}

Work performed under the auspices of the U.S. Department of Energy by Lawrence Livermore National Laboratory under Contract W-7405-ENG-48. This work was supported under activities D-20-53 of the Yucca Mountain Project Spent Fuel Waste form Task (YMP WBS element 1.2.2.3.1.1) and the AECL/USDOE Cooperative Project sponsored by the DOE Office of Civilian Radioactive Waste Management.

\section{REFERENCES}


1. P.A. Finn et al., "Behavior of Spent Fuel Under Unsaturated Conditions," Proc. of Topical Meeting on DOE Spent Nuclear Fuel, Salt Lake City, UT, pp. 421-429 (1994).

2. S. A. Steward and W. J. Gray, "Comparison of Uranium Dissolution Rates from Spent Fuel and Uranium Dioxide," Proc. 5th Annual Intl. High-Level Radio. Waste Mgmt. Conf., Las Vegas, Nevada, May 22-26, 1994, Vol. 4, pp. 2602-8.

3. W.J. Gray, H.L. Leider and S.A. Steward, "Parametric Study of LWR Spent Fuel Dissolution Kinetics," J. Nucl. Mater., 190 (1992) 46-52.

4. S. A. Steward and H. C. Weed, "Modeling of UO2 Aqueous Dissolution Over a Wide Range of Conditions," MRS Symp. Proc., Vol. 333, Scien. Basis for Nucl. Waste Mgmt XVII, pp. 409-416, A. Barkatt and R. A. Van Konynenburg (Eds.), Materials Research Society, Pittsburgh, PA (1994).

5. BBN Software Products Corporation, RS/Discover, Version 2 (1989).

6. Gayer, K.H. and Leider, H., "The Solubility of Uranium Trioxide, $\mathrm{UO}_{3} \cdot \mathrm{H}_{2} \mathrm{O}$, in Solutions of Sodium Hydroxide and Perchloric Acid at $25^{\circ} \mathrm{C}$," JACS, 7ㅜ, 1448 (1955).

7. W. Stumm and J. Morgan, Aquatic Chemistry: An Introduction Emphasizing Chemical Equilibria In Natural Waters, John Wiley and Sons, New York (1981), Chapter 2.14. 
Table 1. Test Matrix for the $\mathrm{UO}_{2+\mathrm{x}}$ Dissolution Tests.

\begin{tabular}{|c|c|c|c|c|c|}
\hline Run & OXIDE & $\begin{array}{l}\text { TEMPERATURE } \\
(\operatorname{deg} C)\end{array}$ & $\begin{array}{l}\text { CARBONATE } \\
(\mathrm{mol} / \mathrm{L})\end{array}$ & $\begin{array}{c}\text { PH } \\
\text { Meas./Soln. }\end{array}$ & $\begin{array}{l}\text { DISSOLUTION } \\
\text { RATE } \\
\left(\mathrm{mgU} / \mathrm{m}^{2} \cdot \text { day }\right)\end{array}$ \\
\hline 1 & $\mathrm{U}_{3} \mathrm{O}_{8}$ & 22.9 & 0.02 & $8.6 / 8.0$ & 19 \\
\hline 2 & $\mathrm{UO}_{3} \cdot \mathrm{H}_{2} \mathrm{O}$ & 24.9 & 0.02 & $10.0 / 10.0$ & $\sim 200$ \\
\hline 3 & $\mathrm{U}_{3} \mathrm{O}_{8}$ & 74.8 & 0.02 & $10.3 / 10.0$ & $\sim 200$ \\
\hline 4 & $\mathrm{UO}_{3} \cdot \mathrm{H}_{2} \mathrm{O}$ & 74.7 & 0.02 & $8.6 / 8.0$ & $>1500$ \\
\hline 5 & $\mathrm{U}_{3} \mathrm{O}_{8}$ & 22.9 & 0.0002 & $8.9 / 10.0$ & 0.8 \\
\hline 6 & $\mathrm{UO}_{3} \cdot \mathrm{H}_{2} \mathrm{O}$ & 24.9 & 0.0002 & $7.3 / 8.0$ & $\sim 100$ \\
\hline 7 & $\mathrm{UO}_{3} \cdot \mathrm{H}_{2} \mathrm{O}$ & 74.7 & 0.0002 & $8.3 / 10.0$ & $>150$ \\
\hline 8 & $\mathrm{U}_{3} \mathrm{O}_{8}$ & 74.8 & 0.0002 & $8.1 / 8.0$ & $\sim 6$ \\
\hline 9 & $\mathrm{U}_{3} \mathrm{O}_{8}$ & 22.9 & 0.02 & 10.6/10.0 & 21 \\
\hline 10 & $\mathrm{UO}_{3} \cdot \mathrm{H}_{2} \mathrm{O}$ & 24.9 & 0.0002 & $7.5 / 10.0$ & $>100$ \\
\hline 11 & $\mathrm{UO}_{3} \cdot \mathrm{H}_{2} \mathrm{O}$ & 74.7 & 0.02 & $10.0 / 10.0$ & $>1000$ \\
\hline 12 & $\mathrm{U}_{3} \mathrm{O}_{8}$ & 48.0 & 0.002 & $8.0 / 8.0$ & $\sim 10$ \\
\hline 13 & $\mathrm{U}_{3} \mathrm{O}_{8}$ & 48.0 & 0.02 & $9.0 / 9.0$ & $>100$ \\
\hline 14 & $\mathrm{UO}_{3} \cdot \mathrm{H}_{2} \mathrm{O}$ & 25.0 & 0.002 & $9.0 / 9.0$ & $\sim 120$ \\
\hline 15 & $\mathrm{UO}_{3} \cdot \mathrm{H}_{2} \mathrm{O}$ & 24.9 & 0.02 & $8.6 / 8.0$ & $\sim 700$ \\
\hline 16 & $\mathrm{U}_{3} \mathrm{O}_{8}$ & 22.9 & 0.0002 & $8.4 / 9.0$ & 1.3 \\
\hline 17 & $\mathrm{UO}_{3} \cdot \mathrm{H}_{2} \mathrm{O}$ & 74.7 & 0.0002 & $8.1 / 8.0$ & $>200$ \\
\hline 18 & $\mathrm{U}_{3} \mathrm{O}_{8}$ & 74.8 & 0.02 & 8.6/8.0 & $\sim 150$ \\
\hline 19 & $\mathrm{U}_{3} \mathrm{O}_{8}$ & 74.8 & 0.0002 & $9.3 / 10.0$ & $\sim 3$ \\
\hline 20 & $\mathrm{U}_{3} \mathrm{O}_{8}$ & 74.8 & 0.0002 & $8.1 / 10.0$ & $\sim 4$ \\
\hline 21 & $\mathrm{U}_{3} \mathrm{O}_{8}$ & 21.6 & 0.002 & 8.6/8.0 & $\sim 10$ \\
\hline 22 & $\mathrm{U}_{3} \mathrm{O}_{8}$ & 21.6 & 0.02 & $9.2 / 8.0$ & 8.3 \\
\hline 23 & $\mathrm{UO}_{3} \cdot \mathrm{H}_{2} \mathrm{O}$ & 75.0 & 0.002 & $9.0 / 9.0$ & $>20$ \\
\hline 24 & $\mathrm{U}_{3} \mathrm{O}_{8}$ & 22.9 & 0.002 & 7.9/8.0 & $\sim 5$ \\
\hline 25 & $\mathrm{UO}_{3} \cdot \mathrm{H}_{2} \mathrm{O}$ & 25.0 & 0.02 & $9.0 / 9.0$ & $>1500$ \\
\hline
\end{tabular}


Table 2, Part 1. Comparison of Dissolution Rates at Boundary Conditions

\begin{tabular}{|c|c|c|c|c|c|c|c|}
\hline \multirow[t]{2}{*}{$\mathrm{pH}$} & Carbonate & Oxygen & Temp & & \multicolumn{2}{|c|}{$\begin{array}{l}\text { Dissolution Rate } \\
\left(\mathrm{mgU} / \mathrm{m}^{2} \cdot \text { day }\right)\end{array}$} & \multirow[b]{2}{*}{$\mathrm{UO}_{3} \cdot \mathrm{H}_{2} \mathrm{O}$} \\
\hline & $(\mathrm{mol} / \mathrm{L})$ & (atm) & ${ }^{\circ} \mathrm{C}$ & $\begin{array}{l}\text { Spent Fuel } \\
\text { ATM-103 }\end{array}$ & $\mathrm{UO}_{2}$ & $\mathrm{U}_{3} \mathrm{O}_{8}$ & \\
\hline 8 & 0.0002 & 0.2 & 25 & & 3.9 & $\sim 5$ & $\sim 100$ \\
\hline 8 & 0.0002 & 0.2 & 50 & & 5.4 & & \\
\hline 8 & 0.0002 & 0.2 & 75 & 8.6 & 11 & $\sim 6$ & $>200$ \\
\hline 8 & 0.02 & 0.2 & 25 & 3.5 & 2.4 & 19 & $\sim 700$ \\
\hline 8 & 0.02 & 0.2 & 50 & & 38 & & \\
\hline 8 & 0.02 & 0.2 & 75 & & 54 & $\sim 150$ & $>1500$ \\
\hline 10 & 0.0002 & 0.2 & 25 & 0.63 & 2.5 & 0.8 & $>100$ \\
\hline 10 & 0.0002 & 0.2 & 50 & & 3.1 & & \\
\hline 10 & 0.0002 & 0.2 & 75 & & 6.5 & $\sim 3$ & $>150$ \\
\hline 10 & 0.02 & 0.2 & 25 & & 20 & 21 & $\sim 200$ \\
\hline 10 & 0.02 & 0.2 & 50 & & 26 & & \\
\hline 10 & 0.02 & 0.2 & 75 & 14 & 77 & $\sim 200$ & $>1000$ \\
\hline
\end{tabular}

Table 2, Part 2. Comparison of Dissolution Rates at Intermediate Conditions

\begin{tabular}{cccccccc}
$\mathrm{pH}$ & Carbonate & Oxygen & Temp & \multicolumn{5}{c}{$\begin{array}{c}\text { Dissolution Rates } \\
(\mathrm{mgU} / \mathrm{m} 2 / \text { day })\end{array}$} \\
& & & & & & \\
& $(\mathrm{mol} / \mathrm{L})$ & $(\mathrm{atm})$ & ${ }^{\circ} \mathrm{C}$ & $\begin{array}{c}\text { Spent Fuel } \\
\text { ATM-103 }\end{array}$ & $\mathrm{UO}_{2}$ & $\mathrm{U}_{3} \mathrm{O}_{8}$ & $\mathrm{UO}_{3} \cdot \mathrm{H}_{2} \mathrm{O}$ \\
8 & & & & & & & \\
8 & 0.002 & 0.2 & 25 & & & $\sim 10$ & \\
9 & 0.002 & 0.2 & 50 & & & $\sim 10$ & \\
9 & 0.0002 & 0.2 & 25 & & & 1.3 & \\
9 & 0.002 & 0.2 & 75 & & & $\sim 4$ & \\
9 & 0.002 & 0.2 & 25 & & & & $\sim 120$ \\
9 & 0.002 & 0.2 & 75 & 6.1 & 12 & & $>20$ \\
9 & 0.02 & 0.2 & 25 & 2.8 & 6.7 & 8.3 & $>1500$ \\
9 & 0.02 & 0.2 & 50 & & & $>100$ & \\
10 & 0.002 & 0.2 & 25 & 2.0 & 9.3 & &
\end{tabular}




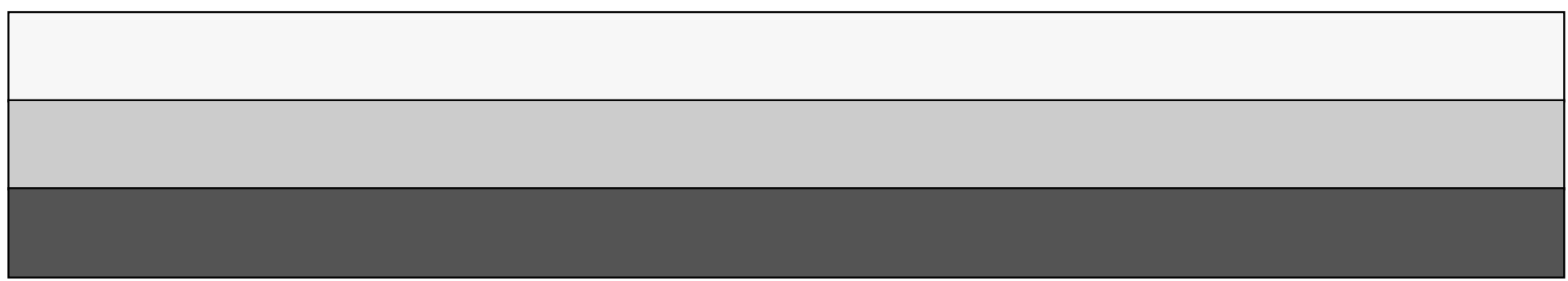

